\title{
EFEKTIFITAS APLIKASI PARKRIGHT SEBAGAI INOVASI SMART PARKING DI WESTMINSTER
}

\author{
Eno Novita Maharani ${ }^{1}$, Eko Priyo Purnomo ${ }^{2}$, Lubna Salsabila ${ }^{3}$ \\ Departement of Government Affairs and Administration I, \\ Jusuf Kalla School of Government, Universitas Muhammadiyah Yogyakarta \\ Email: eno.green2711@gmail.com¹, eko@umy.ac.id², lubnasalsabila@umy.ac.id ${ }^{3}$
}

\begin{abstract}
ABSTRAK
Aplikasi dan layanan smart city kini telah dianggap sebagai sarana strategis untuk mengatasi berbagai permasalahan yang terjadi di dalam kota khususnya masalah area parkir. Smart parking adalah jenis layanan smart yang digunakan untuk mengatasi permasalahan kemacetan lalu lintas dan polusi di dalam kota akibat adanya keterbatasan ruang parkir di kota. Namun, meskipun layanan kota smart terintegrasi oleh teknologi informasi canggih, keberhasilan mereka sangat tergantung pada keterlibatan pengguna, yang sampai saat ini menjadi permasalahan utama dari sistem TIK. Makalah ini menyajikan dan membahas layanan smart parking yakni aplikasi ParkRight di Westminster. Makalah ini akan memaparkan datadata mengenai tingkat keterlibatan pengguna di aplikasi ParkRight. Hasilnya menunjukkan bahwa layanan smart parking yakni aplikasi ParkRight di Westminster berpotensi membantu setiap pengemudi menghemat rata-rata $£ 68$ (62,2 liter) bensin setiap tahun dan mengurangi emisi CO2 sebesar 238,14 kg per mobil per tahun. Namun, kesadaran publik, dan kepuasan pengguna atas layanan aplikasi ParkRight ini masih sangat rendah. Makalah ini menyimpulkan bahwa perlu adanya keterlibatan publik dalam segala keputusan yang berkaitan dengan pembuatan layanan smart seperti smart parking.
\end{abstract}

Kata Kunci: smart city, smart parking, layanan publik

\section{ABSTRACT}

Smart city applications and services have now been considered as a strategic means to overcome various problems that occur within the city, especially parking area problems. Smart parking is a type of smart service that is used to overcome traffic congestion and pollution problems in the city due to the limited parking space in the city. Even though smart city services are integrated by sophisticated information technology, their success depends greatly on user involvement, which until now has been a major problem of ICT systems. This paper presents and discusses the smart parking service, the Park Right application at Westminster. This paper will present data on the level of user involvement in the ParkRight application. The results show that the smart parking service, the ParkRight application at Westminster, has the potential to help each driver save an average of $£ 68$ (62.2 liters) of gasoline each year and reduce CO2 emissions by $238.14 \mathrm{~kg}$ but public awareness and user satisfaction with the ParkRight application service is still very low. The paper concludes that there is a need for public involvement in all decisions related to making smart services such as smart parking.

Keywords: smart city, smart parking, public service 


\section{PENDAHULUAN}

Smart city kini telah menjadi suatu konsep yang digunakan dalam mengatasi berbagai macam permasalahan di dalam kota (Lombardi, Giordano, Farouh, \& Yousef, 2012). Smart city dibangun dengan memanfaatkan serangkaian teknologi informasi dan komunikasi (TIK) berupa perangkat keras, jaringan internert, teknologi penyimpanan data, dan aplikasi perangkat lunak (Peng, Nunes, \& Zheng, 2017). Dalam hal ini, TIK sebagai bagian dari smart city akan memungkinkan menghasilkan layanan baru dimana mencakup semua permasalahan sosial di wilayah perkotaan, termasuk transportasi, kesehatan, keselamatan publik, pendidikan, hingga permasalahan parkir (Neirotti et al., 2014) dan bahkan TIK dapat dilihat sebagai salah satu caru suatu negara untuk sembuh dari tekanan korupsi (Ghayur Adeel, 2006;Salsabila \& Purnomo, 2017).

Pada penelitian ini akan berfokus pada salah satu layanan dalam smart city, yaitu smart parking. Hal ini dikarenakan hasil survei yang dilakukan oleh Shoup menunjukkan bahwa masalah parkir telah terjadi mana-mana di sebagian besar kotakota besar di seluruh dunia dan memakan hingga separuh lahan kota-kota besar seperti , seperti San Francisco yang memakan lahan hingga 80 persen, 81 persen di Los Angeles dan 76 persen di Melbourne, sedangkan New York 18 persen, dan Tokyo 7 persen. Selain itu permasalahan lahan parkir merupakan salah satu penyebab kemacetan lalu lintas dan polusi udara yang bertahan lama di dalam wilayah metropolitan (Shoup 2006;Peng, Nunes, \& Zheng, 2017).
Sistem smart parking merupakan suatu konsep yang dirancang untuk mengatasi masalah kemacetan dengan membantu pengemudi menemukan ruang parkir dengan lebih mudah dengan menggunakan aplikasi smartphone yang terhubung ke sensor yang terletak di dalam jalan (Polycarpou, Lambrinos, \& Protopapadakis, 2013). Sensor tersebut menyediakan data real-time tentang ketersediaan ruang parkir kosong kemudian akan menampilkan peta pada pengemudi yang akan mengarahkan ke ruang parkir kosong tersebut.

Meskipun demikian, layanan smart city pada umumnya termasuk smart parking khususnya didorong oleh teknologi informasi canggih yang sangat bergantung pada keterlibatan warga sebagai pengguna layanan potensialnya (Peng 2015 dalam (Peng et al., 2017)). Namun nyatanya, tingkat keterlibatan pengguna telah menjadi permasalahan yang sulit dalam layanan smart city khususnya smart parking, terutama mengingat perbedaan individu dalam hal usia, pendidikan, keterampilan, tingkat pendapatan, dan pengetahuan warga (Peng et al., 2017).

Salah satu survei telah meneliti mengenai aplikasi smart parking di Washington DC yakni Parkme. Dari 100 orang warga di Washington DC hanya 54 persen yang mengetahui dan telah menggunakan aplikasi ParkMe. Meskipun dari 54 persen pengguna menyatakan bahwa Parkme telah membantu mereka untuk menemukan ruang parkir dengan cepat (Iyer, 2014). Selain itu kasus kurangnya partisipasi dan keterlibatan pengguna telah sering dilaporkan dalam sistem informasi (IS) sebagai penyebab utama kegagalan layanan TIK (Claussen, 
Kretschmer, \& Mayrhofer, 2013). Jika layanan smart city (termasuk smart parking) ingin berhasil, sangat penting bagi calon pengguna untuk sepenuhnya menyadari keberadaan dan kegunaannya, serta untuk dapat dan mau menggunakan layanan tersebut.

Namun beberapa penelitian juga memaparkan beberapa manfaat yang dapat diberikan oleh smart parking. Seperti penelitian yang dilakukan oleh Giuffre dkk dan Elena Polycarpou dkk berdasarkan data yang disediakan oleh sistem smart parking , pemerintah suatu daerah dapat mengurangi terjadinya parkir ilegal, misalnya kendaraan overstay (Giuffrè, Siniscalchi, \& Tesoriere, 2012). Selain itu, Patrick T.I. Lam, Wenjing Yang juga memaparkan bagaimana sistem smart parking terintrerasi dengan teknologi dalam bentuk sebuah aplikasi dapat membantu masalah area parkir di Asia khususnya di Singapura dan Hongkong (Lam \& Yang, 2019).

Selain di Washinton DC, layanan smart parking juga telah diterapkan di salah satu kota besar di London yakni Westminster. Hal ini dikarenakan menurut statistik resmi, ada lebih dari 857 ribu kendaraan terdaftar pertama kali di Westminster selama 2019, (https://assets.publishing.service.gov.uk/). Selain itu menurut Asosiasi Parkir di Inggris, pengemudi di Westminster menghabiskan rata-rata 5,9 menit mencari ruang parkir kosong. Hampir setengah dari orang (sekitar 48 persen) frustrasi oleh kurangnya ruang di daerah mereka karena tindakan parkir yang sembarangan, dan 59 persen marah dengan pengemudi yang buruk mengambil banyak ruang dengan satu

kendaraan(https://www.independent.co.uk/ ).
Oleh karena itu Dewan Kota Westminster telah menginvestasikan sekitar $£ 890.000$ untuk menerapkan sistem smart parking di area Westminster. Sebuah proyek percontohan dilakukan pada tahun 2012 dengan memasang 189 sensor nirkabel di lima jalan Westminster. Berdasarkan keberhasilan proyek percontohan, 3000 sensor lainnya kemudian dipasang di jalanan Westminster pada Juli 2014. Sensor tersebut akan mengumpulkan data real-time tentang status hunian setiap ruang parkir yang terhubung ke aplikasi smartphone yakni ParkRight. Aplikasi ParkRight dibangun untuk memungkinkan warga Westminster (terutama pengemudi) untuk melihat ketersediaan parkir dan menemukan ruang kosong secara real-time. Lebih jauh dari ini, aplikasi ParkRight juga dapat membantu pengguna dalam sejumlah kegiatan terkait parkir lainnya (misalnya memeriksa informasi terperinci tentang biaya parkir dan jam operasional, membayar parkir, dan mengelola sesi parkir)

(https://www.westminster.gov.uk/parkright ).

Maka dari itu penelitian ini akan berfokus pada layanan smart parking yakni ParkRight di Westminster. Peneliti akan berusaha mencari kemungkinan tingkat efektifitas layanan ParkRight di Westminster. Selain itu penelitian ini menganalisis dari data-data sekunder yang telah dikumpulkan yang bertujuan untuk mengetahui tingkat efektifitas dari aplikasi ParkRight sebagai inovasi smart parking di Westminster terutama untuk mengetahui tingkat kesadaran warga Westminster dalam hal penggunaan aplikasi ParkRight. Penelitian ini diharapkan ini dapat memberikan arah yang jelas untuk studi 
smart city di masa depan terutama yang harus dilakukan oleh para peneliti bidang Sistem Informasi.

\section{LANDASAN TEORI}

\subsection{Efektifitas Program}

Menurut Subagyo dalam Ni Wayan, efektifitas program digunakan dalam mengukur kesesuaian suatu program dengan tujuan yang telah ditentukan (Subagyo, 2000;Budiani, 2005). Sutrisno (2001) dalam Pertiwi dan Nurcahyanto memaparkan mengenai ukuran efektifitas dalam sebuah program, yakni sebagai berikut (Sustrisno, 2001;Pertiwi \& Nurcahyanto, 2017):

1) Kesadaran program yakni berkaitan dengan sejauh mana suatu program tersebut diketahui oleh masyarakat.

2) Pemahaman program yakni berkaitan dengan sejauh mana suatu program yang telah di lakukan dapat dipahami oleh masyarakat yang menjalankan program tersebut;

3) Tepat sasaran berkaitan dengan apakah suatu program tersebut berjalan sesuai dengan sasaran yang dikehendaki;

4) Tercapainya tujuan yakni berkaitan dengan bagaimana program tersebut telah mencapai tujuan yang telah ditetapkan;

5) Perubahan nyata yakni untuk mengetahui sejauh mana suatu program tersebut dapat memberikan dampak yang berarti terhadap masyarakat atau lingkungan dimana program tersebut dilaksanakan.

\subsection{Smart Parking}

Sistem smart parking merupakan suatu konsep yang dirancang untuk mengatasi masalah kemacetan dengan membantu pengemudi menemukan ruang parkir gratis dengan lebih mudah. Ini melibatkan penggunaan aplikasi smartphone, yaitu aplikasi yang terhubung ke sensor yang terletak di dalam sensor parking bays (Polycarpou et al., 2013). Berdasarkan pernyataan San Fransisco Municipal Transportation Agency, tujuan dari sistem smart parking adalah untuk memudahkan pengelolaan parkir (Niculescu et al., 2017).

\section{METODE PENELITIAN}

Peneliti ini akan menggunakan metode penelitian kualitatif deskriptif karena kesesuaiannya dengan fokus penelitian serta kemampuannya untuk membantu dalam kontekstualisasi masalah daripada pendekatan lain ( Silverman ; (Purnomo, Anand, \& Choi, 2018). Serta menggunakan data sekunder berupa buku, jurnal akademis, artikel, tesis, disertasi, penelitian terdahulu serta sumber-sumber lainnya yang relevant. Penelitian ini pertama akan berfokus pada pembahasan pemaparan dasar mengenai aplikasi Parkright di Westminster. Kemudian peneliti akan menganalisis ukuran efektifitas aplikasi Parkright di Westminster dengan menggunakan teori efektifitas program oleh Sutrisno dimulai dari ukuran pemahaman program, tepat sasaran, tercapainya tujuan dan perubahan nyata dengan mengumpulkan data-data sekunder yang berkaitan dengan aplikasi Parkright. Setelah itu peneliti akan melanjutkan memaparkan data-data tersebut dalam bentuk teks narasi serta tabel. Setelah itu diakhir peneliti akan menyimpulkan dari data-data yang telah dianalisis apakah aplikasi Parkright sebagai inovasi smart parking di Westminster dapat dikatakan efektif atau tidak. 


\section{HASIL DAN PEMBAHASAN}

\subsection{Deskripsi Aplikasi ParkRight}

Aplikasi ParkRight merupakan sebuah aplikasi yang menyediakan informasi realtime kepada pengemudi tentang ruang parkir mobil yang tidak dihuni melalui platform SmartCould. Aplikasi ParkRight pertama kali dilakukan pada tahun 2012. Hingga sekarang aplikasi ParkRight telah menyediakan sebanyak 41.000 ruang parkir di Westminster dengan sistem pembayaran yang dapat dilakukan melalui aplikasi. Selain itu ParkrRight akan mengidentifikasi ruang parkir kosong yang tersedia dan kemudian akan menampilkan peta yang akan menunjukkan arah ke ruang parkir kosong tersebut. Aplikasi ParkRight dapat di download secara gratis di smartphone yakni di Apple App Store dan Google Play. Selain itu aplikasi ParkRight telah menerima sejumlah penghargaan terkemuka yakni Parking Technology Award di British Parking Awards tahun 2014 dan Award Innovation di Tech Success Awards tahun 2013 (http://www.westminster. gov.uk/parkright).

Berikut beberapa fitur yang dimiliki oleh ParkRight:

1) Sistem pembayaran parkir;

2) Status parkir real-time dengan keterangan ketersediaan: merah (rendah), kuning (sedang) dan hijau (tinggi) serta keterangan tarif.

3) Penunjuk lokasi ruang parkir di jalan dan di tempat parkir;

4) Filter jenis ruang parkir seperti taksi, sepeda motor dan banyak lagi.

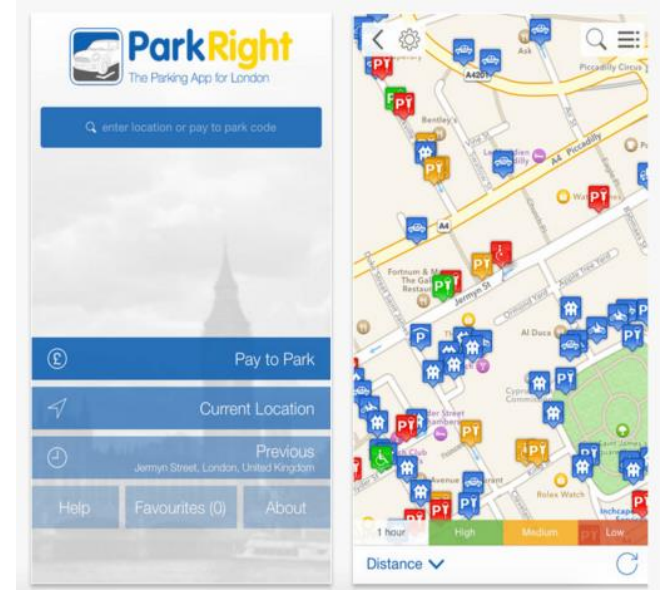

Gambar 1. Tampilan Aplikasi ParkRight

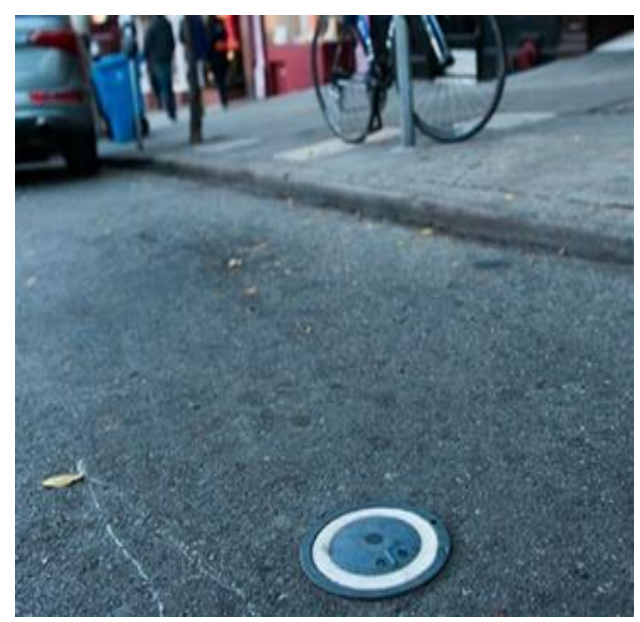

Gambar 2. Sensor parkir ParkRight. (sumber gambar: http://westminsterworld.com/).

\subsection{Analisis Efektifitas Aplikasi ParkRight}

Pada penelitian ini seperti yang dipaparkan pada pendahuluan maka peneliti akan meneliti mengenai efektifitas aplikasi ParkRight sebagai inovasi smart parking di Westminster dengan menggunakan teori efektifitas dari Sustrisno (Pertiwi \& Nurcahyanto, 2017). Adapun hasil analisis sebagai berikut: 
1) Pemahaman dan Kesadaran

Dalam indikator ini, maka peneliti akan menganalisis bagaimana tingkat pemahaman serta kesadaran masyarakat Westminster mengenai aplikasi ParkRight. Berdasarkan data-data yang telah ditemukan oleh peneliti menunjukkan bahwa tingkat kesadaran warga Westminster mengenai keberadaan aplikasi Parkright yakni tergolong masih sangat rendah.

Tabel 1. Pengetahuan terkait manfaat dan fungsi dari Aplikasi ParkRight

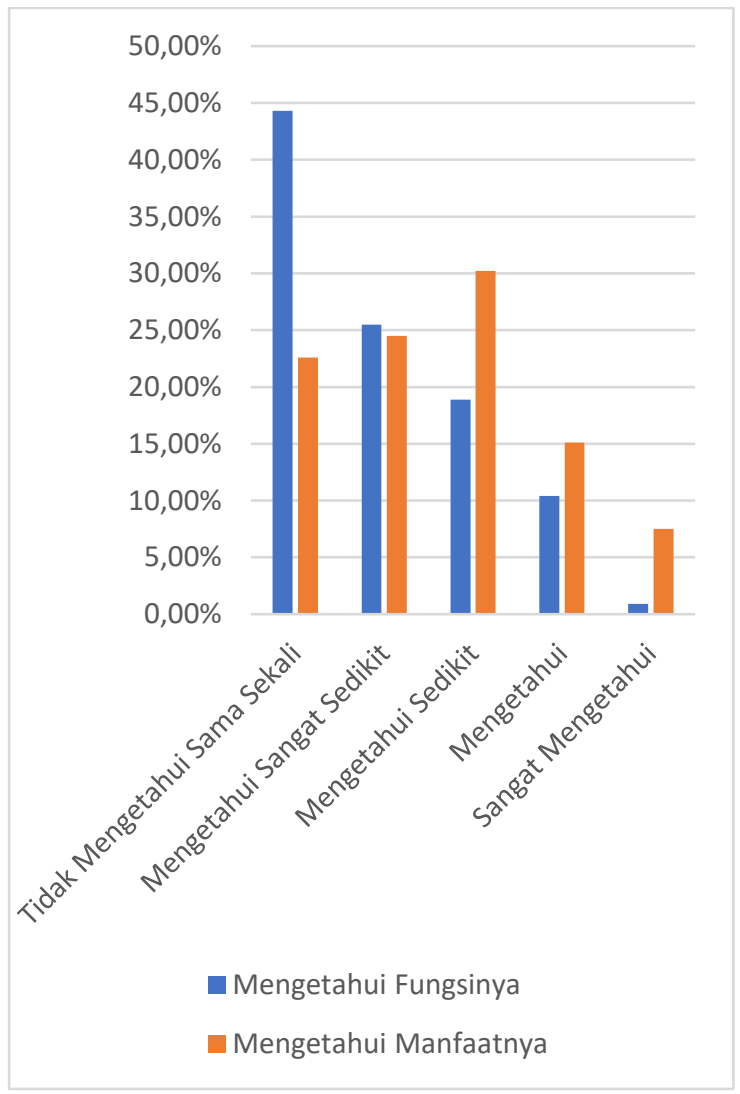

(Sumber Data : Peng, Nunes, \& Zheng, 2017).

Data tersebut diambil dari 212 masyarakat sekitar Westminster dan dari 212 orang sebanyak 156 orang menyatakan bahwa mereka tidak pernah atau hanya sesekali mendengar tentang aplikasi ParkRight tersebut. Selain itu pemahaman mereka mengenai fungsi dari aplikasi ParkRight seperti penyedia informasi ketersediaan ruang parkir kosong secara real-time, sekitar 70 persen dari mereka tidak mengetahui fungsi atau sedikit mengetahui fungsi aplikasi ParkRight. Selain itu lebih dari 47 persen mereka tidak mengetahui manfaat yang dapat diberikan dari aplikasi ParkRight di Westminster seperti menghemat waktu dalam mencari tempat parkir,, menghemat pengguna dan biaya bensin serta mengurangi emisi Co2 (Peng et al., 2017).

Selain itu, pemahaman dan kesadaran masyarakat Westminster mengenai aplikasi ParkRight berdasarkan umur yakni menunjukkan bahwa masyarakat Westminster yang berusia 18-24 tahun memiliki kesadaran dan pemahaman yang rendah mengenai aplikasi ParkRigh. Bahkan 81,5 persen dari mereka menunjukkan bahwa mereka tidak pernah mendengar tentang aplikasi ParkRight (Peng et al., 2017).

Berdasarkan tingkat rendahnya kesadaran dan pemahaman masyarakat Westminster mengenai aplikasi ParkRight. Terdapat dua alasan utama yang menyebabkan hal tersebut terjadi yakni: Pertama; berdasarkan data dalam berita, laporan pemerintah, dan artikel web Google tidak ada yang memberikan informasi pemasaran yang lengkap tentang aplikasi ParkRight. Meskipun pihak berwenang telah membuat halaman web resmi untuk mempromosikan aplikasi ParkRight (https://www.westminster.gov.uk/parkri ght).Namun warga tidak akan mengunjunginya jika mereka bahkan tidak mengetahui adanya layanan ParkRight tersebut. 
Kedua; Terdapat tanda ParkRight yang dipasang di sebagian besar di jalan kota Westminster yang merupakan alat utama dan yang paling mudah diakses bagi masyarakat untuk mengarahkan mereka untuk menggunakan aplikasi ParkRight. Namun, berdasarkan desain tanda ParkRight masih ditemukan sangat bermasalah.

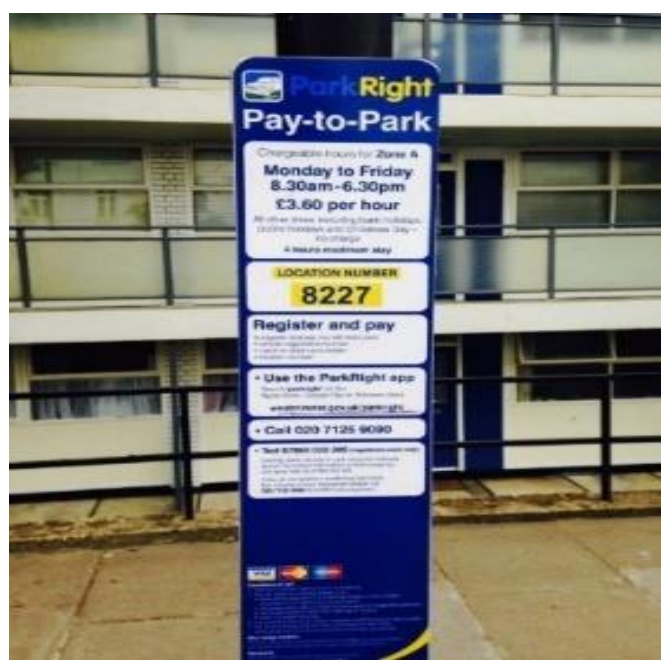

Gambar 2. Tanda ParkRight di Jalan West Westminster (sumber gambar: http://westminsterworld.com/)

Dapat dilihat dari tanda ParkRight (gambar 3). berisi beberapa informasi dalam ruang yang relatif terbatas, dan beberapa informasi tersebut dijabarkan sangat singkat seperti cara mencari aplikasi dan URL situs web resmi. Dalam memberikan pesan teks, tanda ParkRight dapat dilihat hanya menggunakan gambar dan warna yang sangat terbatas (gambar 3). Maka dari itu seharusnya tanda ParkRight tersebut apabila dijadikan sebagai sarana utama promosi harus dirancang dengan baik agar sesuai dengan selera masyarakat. Sehingga dapat menarik perhatian masyarakat Westminster untuk membaca tanda tersebut.
Dapat dilihat dari tanda ParkRight (gambar 3) berisi beberapa informasi dalam ruang yang relatif terbatas, dan beberapa informasi tersebut dijabarkan sangat singkat seperti cara mencari aplikasi dan URL situs web resmi. Dalam memberikan pesan teks, tanda ParkRight dapat dilihat hanya menggunakan gambar dan warna yang sangat terbatas (gambar 3). Maka dari itu seharusnya tanda ParkRight tersebut apabila dijadikan sebagai sarana utama promosi harus dirancang dengan baik agar sesuai dengan selera masyarakat. Sehingga dapat menarik perhatian masyarakat Westminster untuk membaca tanda tersebut.

\section{2) Tepat Sasaran}

Seperti disebutkan sebelumnya, aplikasi ParkRight menerima sejumlah penghargaan terkemuka, misalnya Parking Teknologi Award di Awards Parkir Inggris tahun 2014 dan Innovation Award pada tahun 2013. Namun berdasarkan tingkat kepuasan pengguna aplikasi ParkRight masih terbilang sangat rendah. Hal ini berdasarkan rentan waktu dirilisnya aplikasi ParkRight yakni 27 Desember 2014 hingga 15 Desember 2019. Aplikasi ParkRight telah mempunyai 906 ulasan (Google Store) dengan tingkat kepuasan rata-rata pengguna sebesar 3,7 (dari skor maksimal 5) dengan rata-rata ulasan memberikan peringkat 5 atau 1 yang menunjukkan ketidakpuasan dan kekecewaan pengguna menggunakan aplikasi ParkRight.

Berdasarkan analisis konten tanggapan ulasan pengguna yang dikumpulkan, peneliti mengidentifikasi tiga kategori masalah penggunaan yang 
menyebabkan tingkat kepuasan pengguna yang rendah dari aplikasi ParkRight yakni kegunaannya yang rendah, bug teknis yang persisten, dan defisiensi fungsional.

3) Tercapainya Tujuan

Berdasarkan pemaparan tujuan aplikasi Parkright yang dijabarkan pada Google Store yakni aplikasi Park Right bertujuan untuk memudahkan dalam pengguna dalam menemukan ketersediaan ruang parkir kosong secara real-time, membantu pengguna dalam menunjukkan jalan kearah ruang parkir kosong yang tersedia, serta memberikan kemudahan pengguna dalam pembayaran parkir. Namun dari tujuan tersebut berdasarkan hasil analisis ulasan aplikasi ParkRight justru menimbulkan banyakan kekecewaan karena fitur-fitur tersebut justru menimbulkan berbagai macam masalah.

a) Dalam hal menunjukkan ketersediaan ruang parkir kosong secara real-time sebanyak 3000 ruang di area West End di London, ketersediaan tersebut sebenarnya diperbarui setiap 1 menit dan hanya benar di waktu pencarian. Sebagai akibatnya, pengguna harus sering menyegarkan layar secara manual untuk mendapatkan informasi yang diperbarui. Masalahnya adalah banyak pengguna yang khawatir apabila mereka sedang membaca peta yang ditunjukkan dalam aplikasi saat mengemudi dan ketika mereka harus terus memperbarui peta untuk mendapatkan ketersediaan terbaru, dikhawatirkan akan menimbulkan situasi berisiko seperti kecelakaan dll.

b) Permasalahan lain yakni bug teknis yang persisten. Lebih dari 80 persen komentar melaporkan beberapa bug teknis yang ada di aplikasi ParkRight. Pengguna mengeluh bahwa aplikasi sering macet tanpa alasan misalnya, setelah mereka menekan tombol "Pay to Park" sering terjadi tampilan halaman akan berubah menjadi layar putih dan kemudian aplikasi mogok. Pada kasus lain ketika pengguna memasukkan semua detail pendaftaran dengan benar, aplikasi masih menunjukkan bahwa rincian tersebut salah atau tidak memadai, sehingga proses pendaftaran tidak dapat diselesaikan. Kasus yang lebih buruk yakni ketika pengguna mengetikkan kode parkir lokal untuk mencari ruang tertentu, sistem justru tidak mengenalinya atau menawari mereka parkir di negara lain misalnya Jerman atau Swiss. Banyak pengguna kecewa dengan bug teknis yang sampai ini tidak diperbaiki. Mereka bahkan mempertanyakan apakah penyedia layanan telah melakukan pengujian yang tepat sebelum merilis aplikasi ParkRight.

c) Permasalahan pada sistem pembayaran yang rumit. Banyak pengguna menyatakan bahwa tidak ada konfirmasi dari sistem setelah pembayaran yang telah dilakukan. Aplikasi ini juga tidak memberi tahu mereka berapa lama mereka parkir. Akibatnya, mereka selalu perlu memanggil pusat operasi untuk mengecek durasi parkir untuk menghindari potensi kesalahan pembayaran. Permasalahan lain yakni meskipun aplikasi ParkRight menunjukkan ketersediaan parkir real-time kepada pengguna, itu tidak memungkinkan mereka untuk memesan tempat. Hal ini 
dikarenakan, ruang kosong tersebut dapat diambil oleh pengemudi lain kapan saja.

4) Perubahan Nyata

Permasalahan utama yang terjadi di Westminster yakni berkaitan dengan lamanya waktu pengemudi ketika mencari ruang parkir kosong yang tersedia. Aplikasi ParkRigh di Westminster telah mengatasi hal tersebut. Hal ini terbukti bahwa masyarakat Westminster yang awalnya perlu menghabiskan rata-rata 17,65 menit untuk mencari tempat parkir di jalan di daerah West End. Setelah mereka yang menggunakan aplikasi ParkRight, waktu pencarian parkir rata-rata mereka berkurang menjadi 10,17 menit. Dengan kata lain, aplikasi ParkRight telah membantu pengemudi London menghemat rata-rata 7,48 menit. Selain itu aplikasi ParkRight London berpotensi memberikan manfaat yang sangat besar bagi individu dan kota Westminster. Pada tingkat individu, layanan ini berpotensi membantu setiap pengemudi menghemat rata-rata $£ 68$ (62,2 liter) pada bensin setiap tahun dan mengurangi emisi $\mathrm{CO} 2$ sebesar 238, $14 \mathrm{~kg}$ per mobil per tahun. Di tingkat kota, sistem parkir pintar dapat membantu Westminster menghemat bensin senilai $£ 183,6$ juta per tahun dan mengurangi emisi $\mathrm{CO} 2$ tahunan sebesar 642.978 ton (Peng, Nunes, \& Zheng, 2017).

\section{SIMPULAN DAN SARAN}

Berdasarkan hasil analisis mengenai efektifitas aplikasi Parkight yang masih rendah serta masih terdapat berbagai macam permasalahan sistem di dalam aplikasi ParkRight itu sendiri. Hal tersebut dapat menyebabkan pemborosan investasi dan akan merusak reputasi dan citra otoritas dan penyedia layanan lokal. Meskipun begitu aplikasi ParkRight telah membuat perubahan besar di Kota Westminster seperti penghematan waktu mencari ruang parkir, bensin, hingga pengurangan emisis CO2. Selain itu berdasarkan analisis mengenai aplikasi ParkRight ini dapat ditarik sejumlah hal penting yang perlu diketahui untuk pemerintah Westminster dalam menyediakan layanan smart city terutama smart parking yakni:

1) Kesadaran warga negara yang efektif dan strategi pemasaran program harus tertanam sebagai elemen kunci dalam setiap rencana pengembangan smart city. Hal tersebut sangat perlu dilakukan untuk mengidentifikasi dengan benar kelompok pengguna yang dituju serta memahami dengan jelas karakteristik spesifik, latar belakang demografis, dan minat pengguna, untuk menghindari kesalahan iklan yang dibuat dalam kasus aplikasi ParkRight. Hal tersebut juga untuk menghindari agar suatu layanan dalam smart city yang dirancang dan dikembangkan dengan bukan merupakan kebutuhan warga negara,

2) Dalam kasus aplikasi ParkRightdi London, penyedia layanan tampaknya melakukan upaya penting dalam mengembangkan dan mengimplementasikan layanan, tetapi mereka tampaknya tidak menangani tugas pemeliharaan sistem dan peningkatan dalam fase pasca implementasi dengan benar. Akibatnya, banyak permasalahan teknis yang justru menyelutikan pengguna.

3) Selain itu permasalahan utama pada aplikasi ParkRight ini yakni terkait pengemudi tidak dapat memesan ruang kosong parkir dengan menggunakan aplikasi ParkRight. Karena itu mereka merasa tidak ada gunanya mengikuti aplikasi untuk pergi ke ruang yang bisa diambil oleh pengemudi lain kapan saja. Maka dari itu solusi yang masuk akal 
yang dapat diadopsi oleh Pemerintah yakni mengintegrasikan sistem ParkRight on-street yang baru dengan Sistem PGI. Sistem PGI sering memiliki fungsi reservasi, dan secara efektif dapat mencegah mobil tanpa reservasi masuk ke garasi ketika semua ruang ditempati atau dipesan.

\section{DAFTAR PUSTAKA}

Amari, A., Moussaid, L., \& Tallal, S. (2019). A Smart Parking for Invisible Disabilities. 1-6. https://doi.org/10.1007/978-3-03012048-1_1

Ang, J. T., Chin, S. W., Chin, J. H., Choo, Z. X., \& Chang, Y. M. (2013). ISCAPS - Innovative smart car park system integrated with NFC technology and e-Valet function. 2013 World Congress on Computer and Information Technology, WCCIT 2013. https://doi.org/10.1109/WCCIT.2013. 6618762

Claussen, J., Kretschmer, T., \& Mayrhofer, P. (2013). The effects of rewarding user engagement: The case of Facebook apps. Information Systems Research, 24(1), 186-200. https://doi.org/10.1287/isre.1120.046 7

Dhakne, S., Kengar, U., R.S., P. S., Bhagat, A., \& Chavan, A. (2016). Smart Car Parking System. Ijarcce, 5(12), 247249.

https://doi.org/10.17148/ijarcce.2016. 51255

Geng, Y., \& Cassandras, C. G. (2012). A new "Smart Parking" System Infrastructure and Implementation. Procedia - Social and Behavioral Sciences, 54, 1278-1287. https://doi.org/10.1016/j.sbspro.2012. 09.842
Geng, Y., \& Cassandras, C. G. (2013). New "smart parking" system based on resource allocation and reservations. IEEE Transactions on Intelligent Transportation Systems, 14(3), 11291139. https://doi.org/10.1109/TITS.2013.22 52428

Giuffrè, T., Siniscalchi, S. M., \& Tesoriere, G. (2012). A Novel Architecture of Parking Management for Smart Cities. Procedia - Social and Behavioral Sciences, 53, 16-28. https://doi.org/10.1016/j.sbspro.2012. 09.856

Iyer, L. (2014). Android Application for Vehicle Parking System : "Park Me." International Journal of Innovations \& Advancements in Computer Science IJIACS, 3(3), 1-7.

Kotb, A. O., Shen, Y. C., Zhu, X., \& Huang, Y. (2016). IParker-A New Smart CarParking System Based on Dynamic Resource Allocation and Pricing. IEEE Transactions on Intelligent Transportation Systems, 17(9), 26372647.

https://doi.org/10.1109/TITS.2016.25 31636

Lam, P. T. I., \& Yang, W. (2019). Application of technology to car parking facilities in Asian smart cities. Journal of Facilities Management, $17(2)$, $142-156$. https://doi.org/10.1108/JFM-05-20180031

Lan, K. C., \& Shih, W. Y. (2014). An intelligent driver location system for smart parking. Expert Systems with Applications, 41(5), 2443-2456. https://doi.org/10.1016/j.eswa.2013.0 9.044

Lin, T., Rivano, H., \& Le Mouel, F. (2017). A Survey of Smart Parking Solutions. IEEE Transactions on Intelligent Transportation Systems, 18(12), 3229-3253. 
https://doi.org/10.1109/TITS.2017.26 85143

Lombardi, P., Giordano, S., Farouh, H., \& Yousef, W. (2012). Modelling the smart city performance. Innovation, 25(2), $137-149$. https://doi.org/10.1080/13511610.201 2.660325

Lu, R., Lin, X., Zhu, H., \& Shen, X. (2009). SPARK: A new VANET-based smart parking scheme for large parking lots. Proceedings - IEEE INFOCOM, 1413-1421.

https://doi.org/10.1109/INFCOM.200 9.5062057

Marquez, M. D., Lara, R. A., \& Gordillo, R. X. (2014). A new prototype of smart parking using wireless sensor networks. 2014 IEEE Colombian Conference on Communications and Computing, COLCOM 2014 Conference Proceedings. https://doi.org/10.1109/ColComCon.2 014.6860418

Neirotti, P., De Marco, A., Cagliano, A. C., Mangano, G., \& Scorrano, F. (2014). Current trends in smart city initiatives: Some stylised facts. Cities, 38, 25-36. https://doi.org/10.1016/j.cities.2013.1 2.010

Niculescu, A. I., Wadhwa, B., \& Quek, E. (2017). Technologies for the future: Evaluating a voice enabled smart city parking application. Proceedings 2016 4th International Conference on User Science and Engineering, $i$-USEr 2016, 46-50. https://doi.org/10.1109/IUSER.2016. 7857932

Peng, G. C. A., Nunes, M. B., \& Zheng, L. (2017). Impacts of low citizen awareness and usage in smart city services: the case of Westminster's smart parking system. Information Systems and E-Business Management, 15(4), 845-876. https://doi.org/10.1007/s10257-016-
0333-8

Pierce, G., \& Shoup, D. (2013). Getting the prices right. Journal of the American Planning Association, 79(1), 67-81. https://doi.org/10.1080/01944363.201 3.787307

Polycarpou, E., Lambrinos, L., \& Protopapadakis, E. (2013). Smart parking solutions for urban areas. 2013 IEEE 14th International Symposium on a World of Wireless, Mobile and Multimedia Networks, WoWMoM 2013. https://doi.org/10.1109/WoWMoM.2 013.6583499

Purnomo, E. P., Anand, P. B., \& Choi, J. W. (2018). The complexity and consequences of the policy implementation dealing with sustainable ideas. Journal of Sustainable Forestry, 37(3), 270-285. https://doi.org/10.1080/10549811.201 7.1406373

Revathi, G., \& Dhulipala, V. R. S. (2012). Smart parking systems and sensors: A survey. 2012 International Conference on Computing, Communication and Applications, $\quad$ ICCCA 2012. https://doi.org/10.1109/ICCCA.2012.6 179195

Salpietro, R., Bedogni, L., Di Felice, M., \& Bononi, L. (2015). Park Here! a smart parking system based on smartphones' embedded sensors and short range Communication Technologies. IEEE World Forum on Internet of Things, WF-IoT 2015 - Proceedings, 18-23. https://doi.org/10.1109/WFIoT.2015.7389020

Salsabila, L., \& Purnomo, E. P. (2017). Establishing and Implementing Good Practices E-Government (A Case Study : e-Government Implementation between Korea and Indonesia). Asean/ Asia Academic Society International Conference (Aasic), 5, 221-229. 
Shoeibi, N., \& Shoeibi, N. (2019). Future of smart parking: Automated valet parking using deep Q-learning. Advances in Intelligent Systems and Computing, 1004, 177-182. https://doi.org/10.1007/978-3-03023946-6_20

Zajam, A., \& Dholay, S. (2018). Detecting Efficient Parking Space Using Smart Parking. 2018 9th International Conference on Computing, Communication and Networking Technologies, ICCCNT 2018, 1-7. https://doi.org/10.1109/ICCCNT.201 8.8493964 